\title{
The Labor Market Effects of Payroll Taxes in a Middle-Income Country: Evidence from Colombia*
}

\author{
Adriana Kugler \\ Department of Economics \\ Universitat Pompeu Fabra
}

\author{
Maurice Kugler \\ Department of Economics \\ University of Southampton
}

July 15,2003

\begin{abstract}
We use a panel of manufacturing plants from Colombia to analyze how the rise in payroll tax rates over the 1980's and 1990's affected the labor market. Our estimates indicate that formal wages fall by between $1.4 \%$ and $2.3 \%$ as a result of a $10 \%$ rise in payroll taxes. This "less-than-full-shifting" is likely to be the result of weak linkages between benefits and taxes and the presence of downward wage rigidities induced by a binding minimum wage in Colombia. Because the costs of taxation are only partly shifted from employers to employees, employment should also fall. Our results indicate that a $10 \%$ increase in payroll taxes lowered formal employment by between $4 \%$ and $5 \%$. In addition, we find less shifting and larger disemployment effects for production than non-production workers. These results suggest that policies aimed at boosting the relative demand of low-skill workers by reducing social security taxes on those with low earnings may be effective in a country like Colombia, especially if tax cuts are targeted to indirect benefits.
\end{abstract}

Keywords: Payroll Taxes, Shifting, Wage Rigidity, Minimum Wages. JEL Codes: J31, J32, H23.

\footnotetext{
* We are grateful to Josh Angrist, Samuel Bentolila, Paul Gertler, Jon Gruber, Larry Lau, Bill Maloney, Barry McCormick, Ernesto May, John Pencavel and seminar participants at Southampton University, at the Center on Economic Development and Policy Reform and at the Latin American and Caribbean Economic Association in Madrid for very useful comments, as well as to the World Bank for providing financial support for the study. The econometric analysis of plant level data from the Manufacturing Census was made possible by the hospitality of the Colombian Bureau of National Statistics, while the second author was visiting. Please address correspondence to: adriana.kugler@upf.edu and maurice.kugler@soton.ac.uk.
} 


\section{Introduction}

Payroll taxes in the form of mandatory contributions by employers are used in most countries to finance the provision of pensions, benefits for disability and maternity, and compensation for work injuries for employees. Payroll taxes and other mandated contributions are as high as $30 \%$ in Europe. In the less-regulated British and North American labor markets these contributions are between $15 \%$ and $20 \%$. This has led some to suggest higher labor costs for employers are partly to blame for lower employment in Europe (see, e.g., the OECD Jobs Study) as well as in middle income countries in Latin America, where mandated contribution rates are sometimes even higher.

These arguments notwithstanding, the theoretical analysis of payroll taxation is not entirely clear cut. When workers value the benefits financed through payroll taxes as much as the contributions cost employers, changes in payroll taxes should be fully shifted from firms to employees in the form of lower wages with no disemployment effects. On the other hand, if wages are rigid or payroll taxes finance benefits not completely accrued by employees, there will be only partial shifting and employment should be affected by payroll taxes.

Empirical evidence on the impact of payroll taxation for different countries is mixed. Previous results range from full-shifting to little shifting and large disemployment effects. ${ }^{1}$ Studies that exploit both cross-section and time series variation seem most likely to find full shifting. For example, Gruber $(1994,1997)$ and Gruber and Krueger (1991), which rely on cross-section and time-series variation in Chile for social security contributions and in the U.S. for disability insurance and maternity benefits, find full wage 
shifting of employer contributions and no disemployment effects. Gruber (1997) notes, however, that "the applicability of the [U.S.] studies to other types of payroll taxation and to other countries is uncertain." This is because there may be a closer tax-benefit linkage in the case of disability benefits and maternity health insurance than in the case of savings for retirement. In addition, Gruber (1994) and Gruber and Krueger (1991) consider relatively small increases in payroll taxes which can be easily passed on as lower wages, while Gruber (1997) considers a large reduction in payroll taxes in Chile which can be passed on as higher wages. Downward wage rigidities may make it more difficult to shift a large increase in payroll taxes on to workers.

As in Gruber (1997), we examine the effects of changes in payroll taxes on formal employment and wages in Latin America. In particular, we look at the effects of increases in payroll taxes in Colombia over the 1980's and 1990's and, in particular, at the large increase in payroll taxes for pensions and health of $10.5 \%$ following the Colombian social security reform of 1993. It is especially interesting to contrast the Colombian and the Chilean cases because the effects of payroll taxes may be asymmetric. In particular, if wages are flexible upwards but not down, there could be full shifting in response to a large reduction in payroll taxes but not in response to a large increase. Recent studies suggest that the minimum wage is binding in Colombia (Bell, 1997; Maloney et al., 2003), pointing to an important source of downward wage rigidities there.

Our study uses a balanced panel of plants in the formal sector from the Annual Survey of Manufacturers in Colombia over the period 1982-96. This data set has information on total contributions as well as on wages and employment. Following Gruber

\footnotetext{
${ }^{1}$ For example, Gordon (1972) finds evidence of full-shifting, while Vroman (1974a) finds that only about $40 \%$ of taxes are shifted onto workers as lower wages and Hamermesh (1979) finds that only about a third of
} 
(1997), we construct tax rates for each plant by dividing total contributions by wages rather than by imputing the tax rates based on time and sectoral variation as in other studies. In addition to the temporal variation in payroll taxes, substantial variation in tax rates across Colombian plants comes partly from differences in tax rates between high and low earnings workers, since the payroll tax increase following the 1993 reform was greater for workers earning more than four times the minimum wage. Moreover, cross-section variation in tax rates in the Colombian context also comes from variation in the degree of accident risk across plants, which determines the tax rate applied to different employers for work injury.

Estimates controlling for plant-specific trends suggest a $10 \%$ increase in payroll taxes reduces wages by between $1.4 \%$ and $2.3 \%$ and employment by between $4 \%$ and $5 \%$. There appears to be less shifting and greater disemployment for production than for nonproduction workers. Less shifting and more disemployment for production workers may be due to the fact that the minimum wage is more likely to bind for this group of workers and also due to the weaker link between benefits and contributions for these workers. An implication of these results is that reductions in payroll taxes for low-wage workers, often proposed as a way to boost the relative demand of low-skill workers, may be an effective measure to reduce unemployment among young and unskilled workers in Colombia, especially if tax cuts are targeted to indirect benefits.

The paper is organized as follows. Section 2 illustrates the well known effects of payroll taxes in the benchmark case with a competitive labor market. We then show that this result does not change when downward wage rigidities come from the payment of efficiency wages. On the other hand, a binding minimum wage does limit the ability to shift wages and generates disemployment effects. Section 3 describes the Colombian the contributions for social security are shifted to workers as lower wages. 
institutional background and the changes in mandated payroll taxes in Colombia over the 1980's and 1990's, including changes after the Colombian social security reform of 1993. Section 4 describes the data and presents the results. Section 5 concludes.

\section{Theoretical Effects of Payroll Taxes}

In this section we discuss the impact of payroll taxes on wages and employment in different labor market environments. We begin by showing the well-known effects of payroll taxes in a competitive labor market.

The representative firm chooses employment, $\mathrm{L}_{\mathrm{i}}$, to maximize profits,

$$
\pi_{\mathrm{i}}=\mathrm{pF}\left(\mathrm{L}_{\mathrm{i}}\right)-\mathrm{w}(1+\tau) \mathrm{L}_{\mathrm{i}}
$$

taking the price, $\mathrm{p}$, the wage, w, and the employment level of other firms as given, where $\mathrm{F}\left(\mathrm{L}_{\mathrm{i}}\right)$ is a production function subject to decreasing returns and $\tau$ is the payroll tax firms have to pay out of their wage bill. There are $\mathrm{M}$ identical firms in the economy, so that $\mathrm{L}=\mathrm{ML}_{\mathrm{i}}$, and from the first-order condition aggregate labor demand is given by,

$$
\mathrm{pF}^{\prime}(\mathrm{L})=\mathrm{w}(1+\tau)
$$

The market-clearing wage and employment levels are set to equate labor demand and supply. Labor supply depends on the wage, and on total population, $\mathrm{N}$ :

$$
\mathrm{L}=[\mathrm{w}(1+\mathrm{b} \tau)]^{\varepsilon} \mathrm{N}
$$

where $\varepsilon$ is the labor supply elasticity and b is the workers' valuation of the benefit (i.e., $b=$ 1 implies a perfect link between benefits and contributions). To see the effect of taxes on wages and employment, we first substitute (2) into (1) and take the derivative with respect to the tax rate, which yields,

$$
\mathrm{d} \ln w / \mathrm{d} \tau=-[-\varepsilon(1+\tau) / \eta+1] /[-\varepsilon(1+\tau) / \eta+(1+\tau)]
$$


where $\eta$ is the labor demand elasticity. ${ }^{2}$ The effect of payroll taxes on employment is then obtained by taking the derivative of (1) with respect to the tax rate and re-arranging:

$$
\mathrm{d} \ln L / \mathrm{d} \tau=\{[\mathrm{d} \ln \mathrm{w} / \mathrm{d} \tau](1+\tau)+1\}(\mathrm{w} / \mathrm{L}),
$$

which equals zero when the tax-benefit link is perfect, $b=1$, when the labor supply is perfectly inelastic, $\varepsilon=0$, and when the labor demand elasticity is perfectly elastic, $\eta \rightarrow \infty .^{3}$ This is because in all three cases taxes are fully shifted to workers as lower wages, so there are no disemployment effects.

Downward wage rigidities may, however, limit the ability of firms to pass payroll taxes in the form of lower wages, even under the three cases mentioned above. We examine the impact of payroll taxes in an efficiency wage model a-lá Shapiro and Stiglitz (1984) to explore whether the implications of payroll taxes change under this source of wage rigidities. The firm's maximization problem is as before, where workers are assumed to produce one unit of labor unless they shirk, but now, given imperfect monitoring, the firm also chooses a wage as to avoid shirking. The firm chooses the wage that satisfies the no-shirking condition, such that the expected value of working is greater or equal to the expected value of shirking to the worker. As shown in the Appendix, the lowest efficiency wage, $\mathrm{w}^{\mathrm{e}}$, that satisfies the no-shirking condition is given by

$$
\mathrm{w}^{\mathrm{e}}=\{\mathrm{e}+\mathrm{z}+[(\mathrm{r}+\lambda / \mathrm{u}) \mathrm{e} / \mathrm{\kappa}] /(1+\mathrm{b} \tau)\}
$$

where $\mathrm{e}$ is the disutility of effort, $\mathrm{z}$ are unemployment benefits, $\mathrm{r}$ is the discount rate, $\lambda$ is the instantaneous probability of an exogenous separation, $\kappa$ is the instantaneous probability

\footnotetext{
${ }^{2}$ This expression can also be written to show how the tax-benefit linkage, b, affects shifting. In particular, it can be written as dlnw/d $\tau=-\left\{\left[-\mathrm{pF}^{\prime \prime}(\mathrm{L}) \varepsilon[\mathrm{w}(1+\mathrm{b} \tau)]^{\varepsilon-1} \mathrm{Nb}\right]+1\right\} /\left\{-\mathrm{pF}^{\prime \prime}(\mathrm{L}) \varepsilon[\mathrm{w}(1+\mathrm{b} \tau)]^{\varepsilon-1} \mathrm{~N}(1+\mathrm{b} \tau)+(1+\tau)\right\}$. ${ }^{3}$ As we discuss below, weak linkages in the Colombian context may be one reason to expect "less-than-full shifting" in this country. In addition, while we know of no estimates of labor supply elasticities, one may suspect the supply of formal labor to be fairly elastic in the Colombian context as workers can move between
} 
of getting caught shirking, $\mathrm{u}=(\mathrm{N}-\mathrm{L}) / \mathrm{N}$ is the unemployment rate, and $\mathrm{b}$ and $\tau$ are as before, the workers' valuation of the benefits and the tax rate. The employment level is determined by substituting this wage into the labor demand condition, equation (1),

$$
\mathrm{pF}^{\prime}(\mathrm{L})=\{\mathrm{e}+\mathrm{z}+[(\mathrm{r}+\lambda / \mathrm{u}) \mathrm{e} / \kappa] /(1+\mathrm{b} \tau)\}(1+\tau)
$$

As in the market-clearing case, payroll taxes have no effects on employment if there is a perfect link between benefits and contributions, i.e., $b=1$, because payroll taxes are passed on to workers in the form of lower wages. This can be seen by taking the derivative of the efficiency wage and employment with respect to the payroll tax:

$$
\begin{gathered}
\mathrm{dln} \mathrm{w}^{\mathrm{e}} / \mathrm{d} \tau=-\mathrm{b} /(1+\mathrm{b} \tau), \\
\mathrm{d} \ln L / \mathrm{d} \tau=\left[\left(\mathrm{dln} \mathrm{w}^{\mathrm{e}} / \mathrm{d} \tau\right)(1+\tau)+1\right]\left(\mathrm{w}^{\mathrm{e}} / \mathrm{L}\right) .
\end{gathered}
$$

Figure 1 shows that with efficiency wages, the payroll tax not only shifts the labor demand curve to the left but it also flattens the effort supply or no-shirking curve. The flattening up of the no-shirking curve is greater when there is a perfect link between benefits and contributions. In this case, the flattening of the no-shirking curve is enough to counteract the left shift of the demand curve, generating no net effect on employment. ${ }^{4}$ Consequently, as in a competitive labor market, the perfect link between benefits and contributions implies no disemployment effects.

If wage rigidities come from a government mandated minimum wage, $\overline{\mathrm{w}}$, then the firm's problem is as before but the wage is given by the maximum between $\overline{\mathrm{w}}$ and the

formal and informal employment. An elastic labor supply probably also contributes to "less-than-fullshifting" in the Colombian context.

${ }^{4}$ Lang (2003) examines the impact of payroll taxes in an efficiency wage model. However, in contrast to the Shapiro and Stiglitz (1984) model and other models with efficiency wages, his set-up assumes that the level of effort does not depend on the unemployment rate in equilibrium. For this reason, he finds that payroll taxes increase efficiency wages. In Lang's model firms reduce employment and this requires an increase in the level of worker effort and thus in wages, but because in his set-up wages do not depend on the unemployment rate the lower employment does not affect wages in his model. By contrast, in our model a-lá 
market-clearing wage, $\mathrm{w}^{*}$, given by $\mathrm{pF}^{\prime}\left(\left[\mathrm{w}^{*}(1+\mathrm{b} \tau)\right]^{\varepsilon} \mathrm{N}\right)=\mathrm{w}^{*}(1+\tau)$, or by the maximum between $\overline{\mathrm{w}}$ and $\mathrm{w}^{\mathrm{e}}$ if efficiency wages are paid. In the case when the minimum wage is binding so that $\overline{\mathrm{w}}>\mathrm{w}^{\mathrm{e}}>\mathrm{w}^{*}$, the employment level is given by,

$$
\mathrm{pF}^{\prime}(\mathrm{L})=\overline{\mathrm{w}}(1+\tau)
$$

In this case, there is excess supply of labor and involuntary unemployment. Moreover, the payroll tax always reduces employment in this case, since the payroll taxes cannot be fully shifted to workers as lower wages. As we describe in the next section, not only is the benefit-contribution linkage likely to be weak in the Colombian context, but minimum wages are also likely to be binding.

\section{Institutional Background}

Colombia has long required employers to finance pensions for the old, disabled, and survivors; health benefits for sickness and maternity; work injury benefits in manufacturing and commerce; family allowances and in-kind transfers for low-income households; and training, paid vacations and mandatory bonuses..$^{5}$ Payroll taxes increased along with increasing benefits between $1 \%$ and 2\% in 1982, 1985, 1989 and 1992 and then sharply after 1994 due to the introduction of the 1993 social security reform. Table 1 presents the evolution of mandatory non-wage labor costs starting in 1980. In 1982, mandated payroll contributions increased from $1 \%$ to $2 \%$ as a result of the increase in payroll contributions for training. In 1989, the payroll taxes for in-kind transfers to low-income families

Shapiro and Stiglitz (1984), the lower employment as a result of payroll taxes works as a discipline device, allowing the payment of lower efficiency wages.

${ }^{5}$ In addition, while there is no established unemployment insurance system in Colombia, labor legislation requires employers to pay a one month per year worked severance benefit. After the labor market reform of 1990, the standard system of severance payments which required payments at the time of separation was transformed into a system of individual savings accounts (see Kugler $(1999,2001)$ for a description and analysis of the labor market reform of 1990). Thus, before the labor market reform of 1990, severance 
increased from $2 \%$ to $3 \%$. The first increase in mandated contributions for old age, disability, and survivor pensions occurred in 1985 with an increase from $4.5 \%$ to $6.5 \%$. The payroll contributions for pensions increased again in 1992 by $1.5 \%$ and then the social security reform generated large increases in payroll taxes for pensions from 1994 to 1996 of $5.5 \%$ for employers of workers earning less than four minimum wages and of $6.6 \%$ for employers of workers earning more than four minimum wages. The social security reform also increased payroll contributions for health benefits for the first time in decades between 1994 and 1996 equivalent to 5\%. The social security reform, therefore, increased payroll taxes for pensions and health by $10.5 \%$ and $11.5 \%$ in a two-year period, with between $5 \%$ and $6 \%$ of the increase occurring between 1995 and 1996. This provides a large temporal change in payroll taxes, which is much larger than what is usually observed in high income countries.

Theory tells us that payroll taxes should not affect employment if payroll taxes are completely passed on to workers as lower wages. This is more likely to happen if the workers' valuation of the services financed by payroll taxes coincide with their cost. In Colombia, however, the link between payroll taxes and benefits is not exact because many of the benefits financed through payroll taxes are not directly accrued by employees. For example, while all employers pay taxes to finance family allowances, these allowances are received only by workers with low-income families. Also, while all employers pay taxes for training programs, not all firms take advantage of government-provided training programs. For this reason, payroll taxes are less likely to be passed onto wages in

payments were fixed costs but, after the reform, they were essentially turned into recurrent labor costs such as payroll taxes. 
Colombia than in countries where employer mandated contributions finance only direct benefits.

In addition, the social security reform changed the tax-benefit linkage for pensions. On the one hand, the social security reform introduced minimum benefits for workers previously uncovered by the system, weakening the tax-benefit linkage. On the one hand, by introducing a parallel fully-funded system of individual accounts next to the already existing pay-as-you-go system, the reform contributed to strengthen the tax-benefit linkage. Unlike the pay-as-you-go system which may not return to the beneficiary the amount contributed into the system, individual accounts guarantee direct benefits to contributors to the system and strengthen the tax-benefit linkage. Moreover, trade liberalization increased labor demand elasticities after the reduction of tariffs and quotas in 1991. Unlike in other countries such as Chile, Fajnzylber and Maloney (2000) find evidence that the introduction of Colombia's trade reform in 1991 increased labor demand elasticities for unskilled workers. As shown in the previous section, an increase in labor demand elasticities should increase shifting during the 1990 's compared to the 1980 's. In the empirical analysis, we examine how shifting and disemployment effects changed between the 1980's and 1990's.

As discussed in the previous section, aside from weak tax-benefit linkages, firms may not be able to pass on their higher payroll taxes to workers in the form of lower wages if minimum wages are binding. Evidence on the minimum wage in Colombia over the period of our study suggests that the minimum wage binds for unskilled workers and may have spillover effects for skilled workers in Colombia. Bell (1997) finds that the $10 \%$ rise in the statutory minimum wage during 1981-87 leads to a drop in unskilled employment in the range of $2 \%-12 \%$. Using data from the rotating household panel starting in 1997 , Maloney et al. (2003) find an average elasticity of employment with respect to the 
minimum wage of 0.15 for this later period, which is equivalent to Bell's upper bound. Moreover, Maloney et al. (2003) examine the impact of the minimum wage on the wages and employment of workers at different points in the distribution. They find that the minimum wage in Colombia increases wages and reduces employment for those close to the minimum wage but also for those higher up in the distribution because of a numeraire effect. An important implication of these results is that minimum wages generate real rigidities not only for unskilled but also for skilled workers.

\section{Empirical Analysis}

\subsection{Data Description}

To analyze the impact of payroll taxes on employment and labor costs, we exploit the temporal variation induced by the statutory rise in employer contributions as a percentage of wages and the cross-sectional variation due to heterogeneity in payroll taxes across plants. Our sample consists of a balanced panel of 235 plants in the formal sector from the Colombian Manufacturing Survey for the 1982-1996 period. ${ }^{6}$ The trends in our sample coincide with the general picture in manufacturing as a whole. Table 2 shows the continuous rise in the real wage and the drop in employment since $1991 .^{7}$

Table 2 also shows the trend in average tax rates over the sample period. The average tax rate is calculated as the ratio of total contributions to the wage bill. The table shows the upward trend over the 1980's, a drop in the early 1990's and the sharp rise in tax

\footnotetext{
${ }^{6}$ The Colombian Manufacturing Survey only samples firms with more than 10 employees. All firms in our sample report positive payroll taxes, thus, implying compliance with labor legislation (at least for some of their employees) and participation in the formal sector. We focus on a balanced panel, because we are interested in the impact of payroll taxes on the internal margin. We concentrate on the impact of payroll taxes on the internal margin because spurious entry and exit resulting from changes in the survey methodology over the 1990's makes it more difficult to estimate effects on the external margin. In this sense, we probably provide a lower bound on the impact of payroll taxes on formal employment.
} 
rates starting in 1993 coinciding with the statutory changes in payroll taxes reported in Table 1. An advantage of our data, is that while the changes in payroll taxes coincide with the statutory changes, we can rely on actual information of the payroll tax cost rather than having to impute the average cost to plants based on sector and time period and, thus, we can also exploit the variation in tax rates across plants.

The data shows substantial variation in tax rates across plants. Figures 2 and 3 show the distribution of the average tax rate for non-production and production workers, respectively, during the 1980 's. The figures show substantial variation in the tax rates for both non-production and production workers. The minimum and maximum tax rates of non-production workers are $10 \%$ and $75 \%$, with a mean of $47 \%$. The minimum and maximum tax rates of production workers are $27 \%$ and $74 \%$, with a mean of $45 \%$. Figures 4, 5, and 6 show the distribution of tax rates for both production and non-production workers during the 1990's. Figure 4 shows the distribution of average tax rates in 1992-93, which looks similar to the distribution observed during the 1980's. In contrast, the distribution of average tax rates in Figure 5 for 1993-94 shows a shift of the distribution towards the right and an increase in the mean average tax rate, which is consistent with the increase in statutory payroll taxes after the social security reform. Figure 6 shows a farther shift in the distribution towards the right and an increase in the mean average tax rate to $57 \%$ after the full implementation of the social security reform in 1995-96.

These distributions of average tax rates not only show the temporal change in tax rates, but also substantial cross-sectional variation. There are several sources of actual variation in taxes across plants. First, there is variation in payroll taxes between high and low earnings workers since the payroll tax increase after the 1993 social security reform

\footnotetext{
${ }^{7}$ Wages are deflated by a sector-specific producer price index.
} 
was greater for workers earning more than four times the minimum wage. Second, injury risk variation across plants generates payroll tax differentials because employers' work injury contributions depend on the degree of risk, ranging from $0.35 \%$ to $8.7 \%$ (see Table 1). Third, there is heterogeneity in the share of the wage bill covered by social security because some plants use informal employment and do not pay mandated benefits. Fourth, the variation in employment of temporary workers, who are not subject to some benefits (e.g., paid vacations), also generates differences in tax rates across plants. Finally, there is variation in payroll taxes for paid vacations and bonuses. While minimum mandatory paid vacations and bonuses are half a month or about $4.15 \%$ in payroll taxes, some plants choose to give more paid vacations and bigger bonuses and, consequently, contribute higher payroll taxes for these.

Aside from variation in actual tax rates, measurement error in the tax and wage bills may also contribute to observed differences in tax rates across plants. Classical measurement error in the tax bill will bias the effects of payroll taxes on wages and employment towards zero, while measurement error in the wage bill will bias the results towards a finding of shifting to wages and the effect of payroll taxes on employment towards zero. We follow Gruber's (1997) identification strategy by assuming that there is a dimension of variation along which the true tax rate varies, but the spurious components of the measured tax rate do not. First, we assume that plants systematically overstate or understate the tax rate so that fixed plant-specific measurement error is absorbed by plant effects. We also assume that any spurious time-varying component of tax rates follows linear sector-specific or plant-specific trends. These approaches also help to control for omitted variables correlated with tax rates. For example, these control for the possibility that systematically high wage workplaces are also the ones with the lowest fraction of 
uncovered payroll or the ones with the highest risk of accidents, if the fact that a plant is high wage is mostly fixed over time or follows sector-specific or plant-specific trends.

\subsection{Results}

Table 2 shows that the social security reform of 1993 coincided with an expansion. Following Gruber (1997), we therefore restrict the analysis to years at similar points in the cycle. For the 1980's, we use 1983-1984 and 1989-90 for pairs of expansionary years and 1984-85 and 1988-89 for pairs of recessionary years. For the 1990's, we use 1993-94 and 1995-96 as pairs of years at similar points in the business cycle before and after the full implementation of the social security reform.

The post-1992 data, for which we cannot separate production and non-production workers are used to estimate:

$$
\begin{array}{r}
\Delta \log \left(\mathrm{W}_{\mathrm{ijt}} / \mathrm{E}_{\mathrm{ijt}}\right)=\alpha_{1}+\beta_{1} \Delta \tau_{\mathrm{ijt}}+\theta_{\mathrm{t}}+\mathrm{u}_{\mathrm{ijt}}, \\
\Delta \log \left(\mathrm{E}_{\mathrm{ijt}}\right)=\alpha_{2}+\beta_{2} \Delta \tau_{\mathrm{ijt}}+\theta_{\mathrm{t}}+\mathrm{e}_{\mathrm{ijt}},
\end{array}
$$

where the ratio of total payroll taxes, $\mathrm{T}_{\mathrm{ijt}}$, over total wages, $\mathrm{W}_{\mathrm{ijt}}$, gives the tax rate for plant $\mathrm{i}$ in sector $\mathrm{j}$ at time $\mathrm{t}$, i.e., $\tau_{\mathrm{ijt}}=\left(\mathrm{T}_{\mathrm{ijt}} / \mathrm{W}_{\mathrm{ijt}}\right)$, and where $\mathrm{E}_{\mathrm{ijt}}$ is total employment. These regressions include year effects, $\theta_{t}$, while differencing eliminates plant effects. The identifying assumption is that omitted variables are absorbed by year, sector, and plant controls. We also add sector effects, $\gamma_{j}$, to the specifications in differences to control for sector-specific trends:

$$
\begin{array}{r}
\Delta \log \left(\mathrm{W}_{\mathrm{ijt}} / \mathrm{E}_{\mathrm{ijt}}\right)=\alpha_{1}+\beta_{1} \Delta \tau_{\mathrm{ijt}}+\theta_{\mathrm{t}}+\gamma_{\mathrm{j}}+\mathrm{u}_{\mathrm{ijt}}, \\
\Delta \log \left(\mathrm{E}_{\mathrm{ijt}}\right)=\alpha_{2}+\beta_{2} \Delta \tau_{\mathrm{ijt}}+\theta_{\mathrm{t}}+\gamma_{\mathrm{j}}+\mathrm{e}_{\mathrm{ijt}} .
\end{array}
$$


Finally, we estimate models that control for plant-specific trends by adding plant effects, $\varphi_{\mathrm{i}}$, to the specification in differences:

$$
\begin{array}{r}
\Delta \log \left(\mathrm{W}_{\mathrm{ijt}} / \mathrm{E}_{\mathrm{ijt}}\right)=\alpha_{1}+\beta_{1} \Delta \tau_{\mathrm{ijt}}+\theta_{\mathrm{t}}+\varphi_{\mathrm{i}}+\mathrm{u}_{\mathrm{ijt}}, \\
\Delta \log \left(\mathrm{E}_{\mathrm{ijt}}\right)=\alpha_{2}+\beta_{2} \Delta \tau_{\mathrm{ijt}}+\theta_{\mathrm{t}}+\varphi_{\mathrm{i}}+\mathrm{e}_{\mathrm{ijt}} .
\end{array}
$$

In addition to pooled analyses that group all types of workers, pre-1992 data are used to estimate models that separate production and non-production workers. These models could be written:

$$
\begin{aligned}
\Delta \log \left(\mathrm{W}_{\mathrm{ijkt}} / \mathrm{E}_{\mathrm{ijkt}}\right) & =\alpha_{1}+\beta_{1} \Delta \tau_{\mathrm{ijkt}}+\delta \mathrm{P}_{\mathrm{k}}+\theta_{\mathrm{t}}+\gamma_{\mathrm{j}}+\mathrm{u}_{\mathrm{ijkt}}, \\
\Delta \log \left(\mathrm{E}_{\mathrm{ijkt}}\right) & =\alpha_{2}+\beta_{2} \Delta \tau_{\mathrm{ijkt}}+\delta \mathrm{P}_{\mathrm{k}}+\theta_{\mathrm{t}}+\gamma_{\mathrm{j}}+\mathrm{e}_{\mathrm{ijkt}} .
\end{aligned}
$$

where $\mathrm{P}_{\mathrm{k}}$ is a production/non-production worker dummy. We estimate these differences regressions with and without sector effects. The specifications with sector effects allow the true variation in taxes to be along the plant-year and the plant-year-worker type dimensions controlling for sector-specific trends for each worker type. Again, we add plant effects to (7) and (8) as in the pooled models.

While the data for the 1990's do not disaggregate production and non-production workers, the large temporal change in payroll taxes occurred during this time period after the social security reform. The first two columns in Table 3 report estimates of the impact of payroll taxes on the wages and employment of production and non-production workers during the 1990's. In particular, the first two rows report differences results with and without sector effects estimated using equations (1)-(4). The results without controlling for sector-specific effects suggest that an increase in payroll taxes of a similar magnitude to the increase that followed the 1993 social security reform (i.e., a 10\% increase) reduces wages 
by $1.42 \%$ and employment by $2.73 \%$. Controlling for sector-specific trends shows larger effects on both wages and employment, suggesting measurement error on the tax rate rather than on wages. In particular, the results with sector-specific trends suggest that a $10 \%$ increase in the payroll tax rate reduces wages by $1.87 \%$ and employment by $3.05 \%$. The results controlling for plant-specific trends in the third row show even larger shifting and disemployment effects. In particular, a 10\% increase in the payroll tax rate reduces wages by $2.35 \%$ and employment by $3.84 \%$. This effect on wages is similar in magnitude to the effect of social security taxes on wages found by Hamermesh (1979) for the U.S., though we cannot compare disemployment effects because this study does not examine the impact on employment.

The rest of the columns in Table 3 show the results for the pre-1992 years, pooling together production and non-production workers. In particular, the table reports results with and without controls for sector-specific trends estimated using equations (7) and (8) as well as results with controls for plant-specific trends. The results from the differences specification, which controls for sector-specific trends, show partial shifting of payroll taxes to wages and negative effects on employment. In particular, the results for both the expansion and recession pre-1992 years show that a 10\% increase in payroll taxes during the expansionary years of the 1980's decreases wages by $1.75 \%$ and employment by $2.1 \%$. However, the extent of shifting and the disemployment effects of taxes become larger when plant-specific trends are controlled for. The results for the expansionary pre-1992 years, which control for plant-specific trends, suggest that a $10 \%$ increase in payroll tax rates reduces average wages by $2.27 \%$ and employment by close to $5 \%$. By contrast, the results for the recession pre-1992 years suggest that a $10 \%$ rise in payroll taxes reduces employment by $5 \%$ but lowers wages by only $1.37 \%$. 
The results for the 1980's can be compared with the results for the 1990's to check whether the change in tax-benefit linkages generated by the social security reform affected the effects of payroll taxes on shifting and employment. As discussed above, the social security reform weakened the tax-benefit linkage due to the introduction of minimum pensions. At the same time, the movement from a PAYG system to a fully-funded system probably strengthened the tax-benefit linkage. The results suggest that shifting increased after the introduction of the reform, suggesting the movement to a fully-funded system was probably more important than the introduction of minimum pensions. Moreover, greater shifting could also be explained by an increase in labor demand elasticities during this period. As indicated above, Fajnzylber and Maloney (2000) indeed find evidence that labor demand elasticities increased for blue collar workers in Colombia after trade was liberalized in 1991. Consistent with more shifting, the results also suggest less disemployment after the introduction of the trade and social security reforms in the 1990's.

Table 4 reports results for the pre-1992 years, for which it is possible to separate production and non-production workers. In particular, the table reports results of differences specifications estimated using equations (1) and (2) and of specifications controlling for sector-specific and plant-specific trends estimated using equations (3)-(6). Consistent with minimum wages binding more for production than for non-production workers, these results show less shifting to wages for production than for non-production workers. Moreover, consistent with less shifting for production workers, the results indicate greater negative effects of payroll taxes on the employment of production than of non-production workers. Columns 1-4 report results using data for the expansionary pre1992 years. The results from the differences specifications which control for sectorspecific trends suggest that a $10 \%$ increase in payroll taxes reduce production wages by less 
than $1 \%$ but reduce non-production wages by $2.68 \%$. Consistent with less shifting for production workers, these results also suggest that a $10 \%$ increase in payroll taxes reduces employment for production workers by close to $4 \%$ and for non-production workers by close to $2 \%$. Finally, results controlling for plant-specific trends show greater shifting and bigger disemployment effects for both groups, but continue to show greater shifting for non-production workers. These results suggest that a $10 \%$ increase in payroll taxes reduces the production wages by $1.39 \%$ and non-production wages by $2.89 \%$, while reducing employment of production workers by $5.49 \%$ and employment of non-production workers by $4.9 \%$.

Columns 5-8 in Table 4 report similar results for the recessionary pre-1992 years. As before, the estimates in this table show less shifting and larger disemployment effects for production than for non-production workers as a result of higher payroll taxes. The results in this table, however, show more shifting for production workers and less shifting for non-production workers during recessionary years compared to expansionary years. Non-production workers, who are less likely to be laid-off during recessions, may be less willing to take wage cuts when wages are already low. By contrast, production workers may become more willing to take wage cuts given the threat of layoffs. The differences specification controlling for sector-specific trends suggest that a $10 \%$ increase in payroll taxes reduces the wages and employment of production workers by $1.1 \%$ and $3.25 \%$ and reduces the wages and employment of non-production workers by $1.9 \%$ and $1.97 \%$. As for the expansionary years, controlling for plant-specific trends increases shifting and disemployment effects for both groups, though shifting continues to be greater for nonproduction workers. In particular, the results show that a $10 \%$ increase in payroll taxes reduce production wages by $1.46 \%$ and non-production wages by $2.75 \%$, while reducing 
production employment by $5.14 \%$ and non-production employment by $4.38 \%$. These results, together with the results for production and non-production workers during the expansionary years, suggest that policies aimed at boosting the relative demand of production workers by reducing payroll taxes for this group of workers are likely to be effective.

\section{Summary and Conclusions}

Colombian payroll taxes rose sharply in the 1980s and 1990s, a development that has been blamed for increasing unemployment. As a theoretical matter, the employment consequences of payroll taxes depend on the extent to which they can be passed on to workers in the form of lower wages. Our estimates suggest only about a fifth of the increases in taxes were shifted on to workers through lower wages. This is roughly in line with Hamermesh's (1979) results showing about one-third shifting for US social security payroll taxes. Even less shifting in the Colombian context may be due to relatively high minimum wages and a weaker link between contributions and benefits in the Colombian context.

Complementing the partial shifting result, our findings point to a significant role for increasing payroll taxes in the rise in Colombian unemployment. The estimates suggest that a $10 \%$ increase in payroll taxes reduces formal employment between $4 \%$ and $5 \%$. In addition, there appears to be less shifting and greater negative effects of payroll taxes on formal employment for production than for nonproduction workers. This evidence is consistent with rising unemployment, especially among unskilled workers most likely to be affected by the minimum wage. A natural 
avenue for future research in the Colombian context is an inquiry into whether these changes also contributed to the growth of the informal sector. 


\section{References}

Angrist, Joshua. 1996. "Short-Run Demand for Palestinian Labor," Journal of Labor Economics, 14(3): 425-53.

Beach, Charles and Frederick Balfour. 1983. "Estimated Payroll Tax Incidence and Aggregate Demand for Labour in the United Kingdom," Economica, 50: 35-48.

Bell, Linda. 1997. "The Impact of Minimum Wages in Colombia," Journal of Labor Economics, 15(3): S102-S135.

Daveri, Francesco and Guido Tabellini. 2000. "Unemployment and Taxes: Do Taxes Affect the Rate of Unemployment?," Economic Policy, 49-104.

Fajnzylber, Pablo and William Maloney. 2000. "Labor Demand and Trade Reform in Latin America,” World Bank Policy Research Working Paper No. 2491.

Gordon, Robert. 1972. "Wage-Price Controls and the Shifting Phillips Curve," Brookings Papers on Economic Activity, 2: 385-421.

Gruber, Jonathan. 1997. "The Incidence of Payroll Taxation: Evidence from Chile," Journal of Labor Economics, 15(3): S72-S101.

Gruber, Jonathan. 1994. "The Incidence of Mandated Maternity Benefits," American Economic Review, 84(3): 622-41.

Gruber, Jonathan and Alan Krueger. 1991. "The Incidence of Mandated EmployerProvided Insurance: Lessons from Workers' Compensation Insurance,” in David Bradford, ed., Tax Policy and the Economy, vol. 5: 111-44. Cambridge, Mass.: MIT Press.

Hamermesh, Daniel. 1993. Labor Demand. Princeton: Princeton University Press.

Hamermesh, Daniel. 1979. "New Estimates of the Incidence of the Payroll Tax," Southern Economic Journal, 45: 1208-19.

Holmlund, Bertil. 1983. "Payroll Taxes and Wage Inflation: the Swedish Experience," Scandinavian Journal of Economics, 85(1): 1-15.

Kugler, Adriana, Juan F. Jimeno and Virginia Hernanz. 2003. "Employment Consequences of Restrictive Permanent Contracts: Evidence from Spanish Labor Market Reforms," CEPR Discussion Paper No. 3724.

Kugler, Adriana. 2001. "Forced Savings for a Rainy Day: the Effects of Severance Payments Savings Accounts in Colombia,” CEPR Discussion Paper No. 3197. 
Kugler, Adriana. 1999. "The Impact of Firing Costs on Turnover and Unemployment: Evidence from the Colombian Labour Market Reform," International Tax and Public Finance, 6(3): 389-410.

Kugler, Maurice and Howard Rosenthal. 2000. "Checks and Balances: An Assessment of the Institutional Separation of Political Powers in Colombia," Discussion Paper 0018, Department of Economics, University of Southampton.

Lang, Kevin. 2003. "The Effect of the Payroll Tax on Earnings: A Test of Competing Models of Wage Determination.” Boston University, mimeo.

Maloney, William, Jairo Núñez, Wendy Cunningham, Norbert Fiess, Claudio Montenegro, Edmundo Murrugarra, Mauricio Santamaría, and Claudia Sepulveda. 2003. "Minimum Wages in Latin America," forthcoming in James Heckman and Carmen Pagés, eds., Law and Employment: Lessons from Latin America and the Caribbean. Chicago: Chicago University Press/NBER.

Marrufo, Grecia. 2001. "Financing Social Security Programs in Mexico: Who Bears the Cost?," University of Chicago, mimeo.

Nickell, Stephen and Richard Layard. 1999. "Labor Market Institutions and Economic Performance," in Orley Ashenfelter and David Card, eds., Handbook of Labor Economics, Volume 3: 3029-84.

Nickell, Steven and Brian Bell. 1996. "Would Cutting Payroll Taxes on the Unskilled Have a Significant Impact on Unemployment?," in Denis Snower and Guillermo de la Dehesa, eds., Unemployment Policy: Government Options for the Labour Market, 296-332.

OECD. 1995. OECD Jobs Study: Taxation, Employment, and Unemployment. Paris: OECD.

Shapiro, Carl and Joseph Stiglitz. 1984. "Equilibrium Unemployment as a Worker Discipline Device," American Economic Review, 74: 433-444.

Tullio, Giuseppe. 1987. "Long Run Implications of the Increase in Taxation and Public Debt for Employment and Economic Growth in Europe," European Economic Review, 31: 741-780.

Vroman, Wayne. 1974a. "Employer Payroll Tax Incidence: Empirical Tests with CrossCountry Data," Finances Publiques, 24: 184-200.

Vroman, Wayne. 1974b. "Employer Payroll Taxes and Money Wage Behavior," Applied Economics, 6: 189-204.

Weitenberg, Johannes. 1969. "The Incidence of Social Security Taxes," Finances Publiques, 19: 193-208. 


\section{Appendix}

A firm paying efficiency wages chooses a wage to satisfy the no-shirking condition, such that the expected value of working is greater or equal to the expected value of shirking to the worker. The expected value of working is given by the following asset equation,

$$
\mathrm{rE}_{\mathrm{n}}=\mathrm{w}(1+\mathrm{b} \tau)-\mathrm{e}+\lambda\left(\mathrm{U}-\mathrm{E}_{\mathrm{n}}\right)
$$

an the expected value of shirking is given by the asset equation,

$$
\mathrm{rE}_{\mathrm{s}}=\mathrm{w}(1+\mathrm{b} \tau)+(\lambda+\kappa)\left(\mathrm{U}-\mathrm{E}_{\mathrm{s}}\right)
$$

Similarly, the asset equation of unemployment is,

$$
\mathrm{rU}=\mathrm{z}+\phi(\mathrm{E}-\mathrm{U})
$$

where $\phi$ is the arrival rate of offers and is given by the steady-state condition, such that the flows into unemployment are equal to the flows out of unemployment, $\lambda \mathrm{L}=\phi(\mathrm{N}-\mathrm{L})$, so $\phi=$ $\lambda \mathrm{L} /(\mathrm{N}-\mathrm{L})$. The lowest wage that satisfies the no-shirking condition is the wage such that, $E_{n}=E_{s}$, which implies positive rents, $(E-U)=e / \kappa$. The efficiency wage is found by substituting these rents, the arrival rate of offers, and the value of unemployment into the value of employment,

$$
\mathrm{w}^{\mathrm{e}}=\{\mathrm{e}+\mathrm{z}+[(\mathrm{r}+\lambda / \mathrm{u}) \mathrm{e} / \mathrm{\kappa}] /(1+\mathrm{b} \tau)\} .
$$


Figure 1: Effects of Payroll Taxes on the Labor Demand and No-Shirking Curves

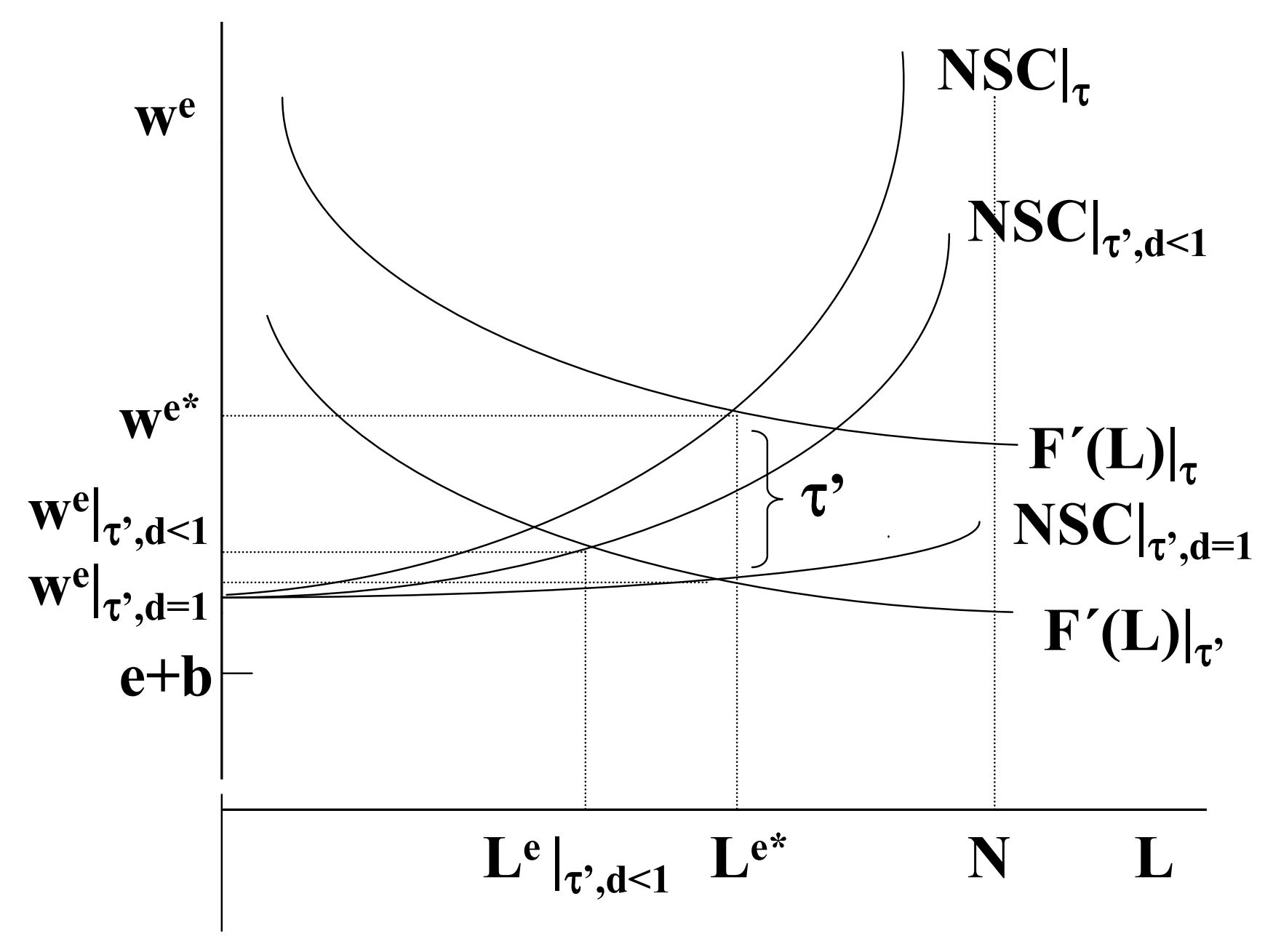


Figure 2: Distribution of Average Tax Rates

for Non-Production Workers, 1982-1991

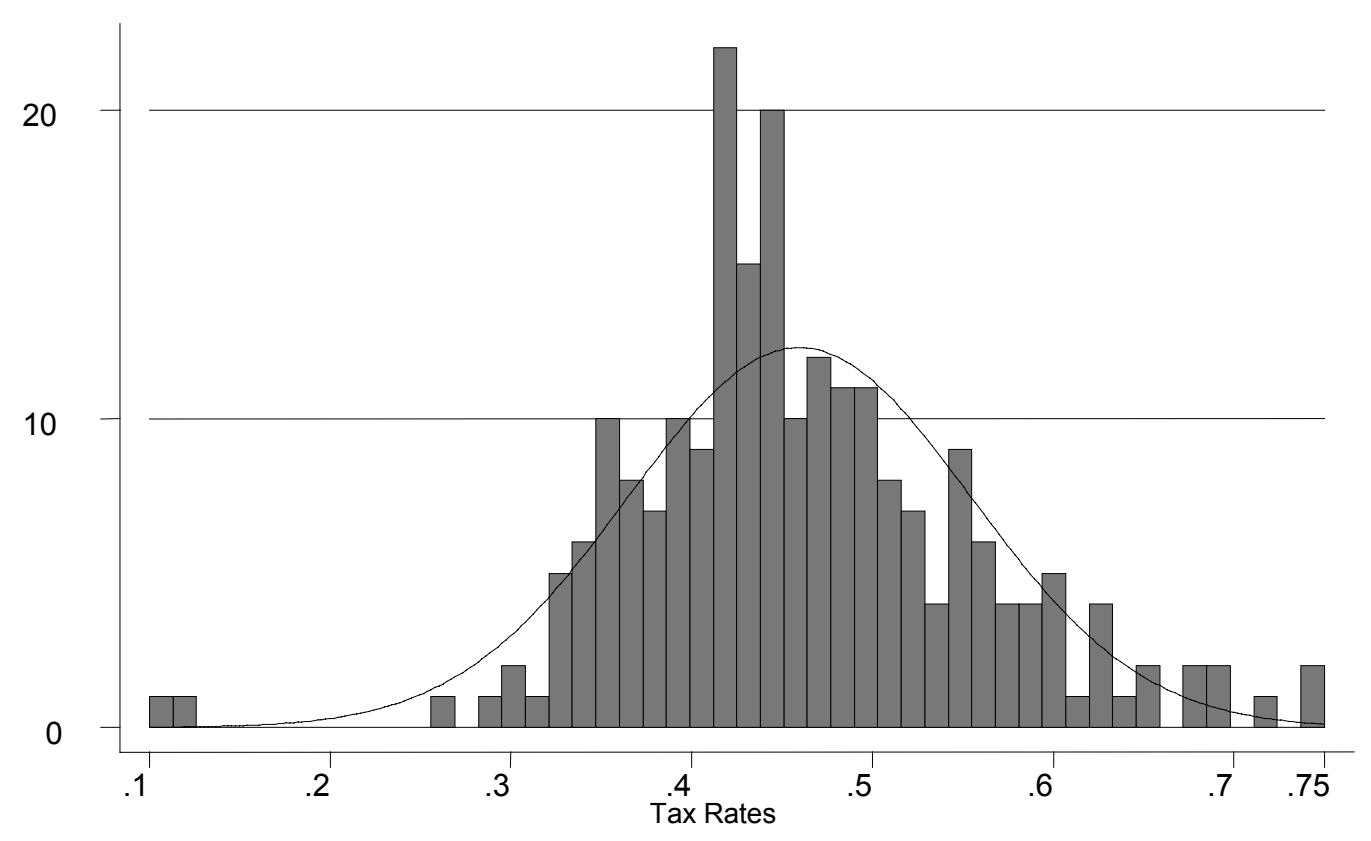

Figure 3: Distribution of Tax Rates

for Production Workers, 1982-91

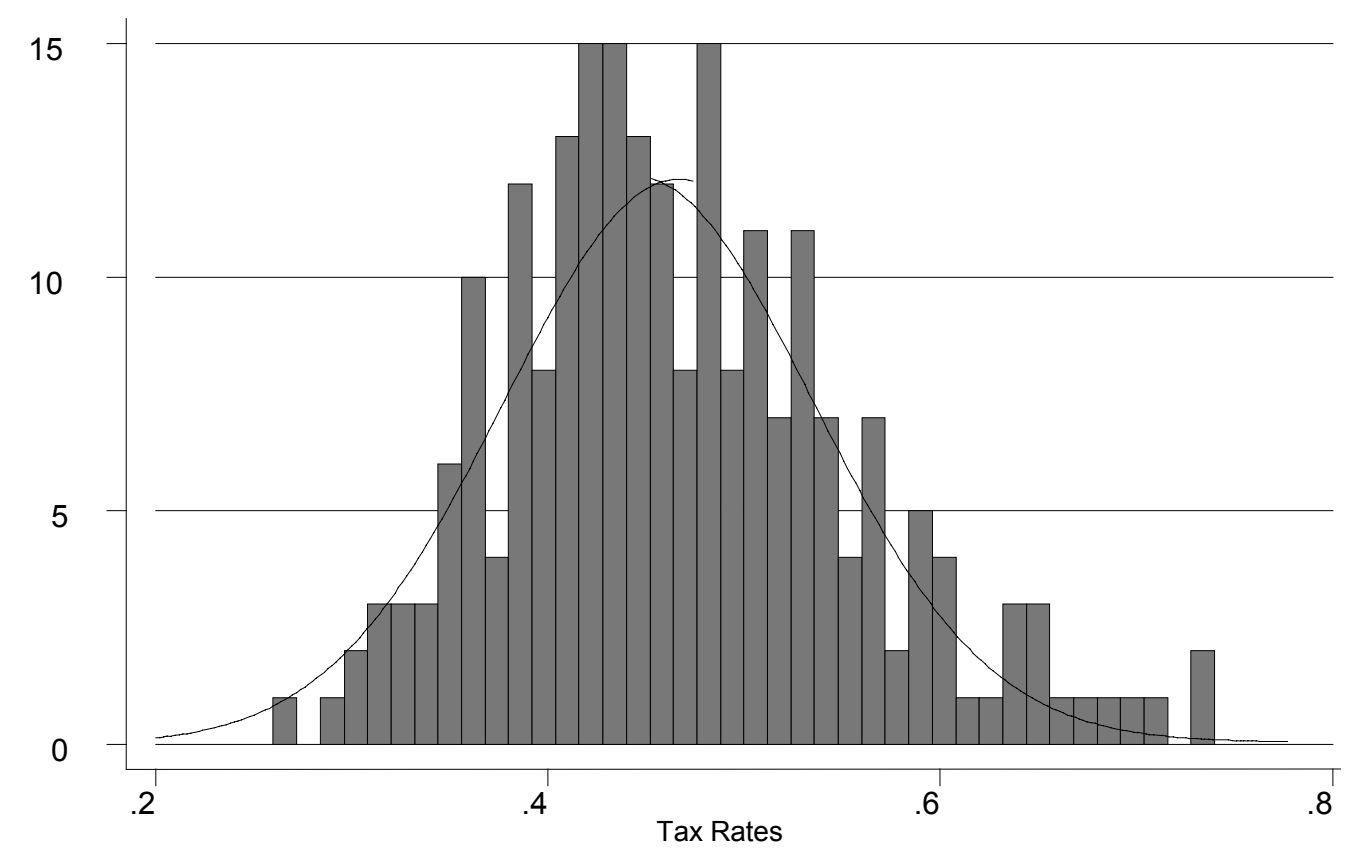


Figure 4: Average Tax Rates, 1992-93

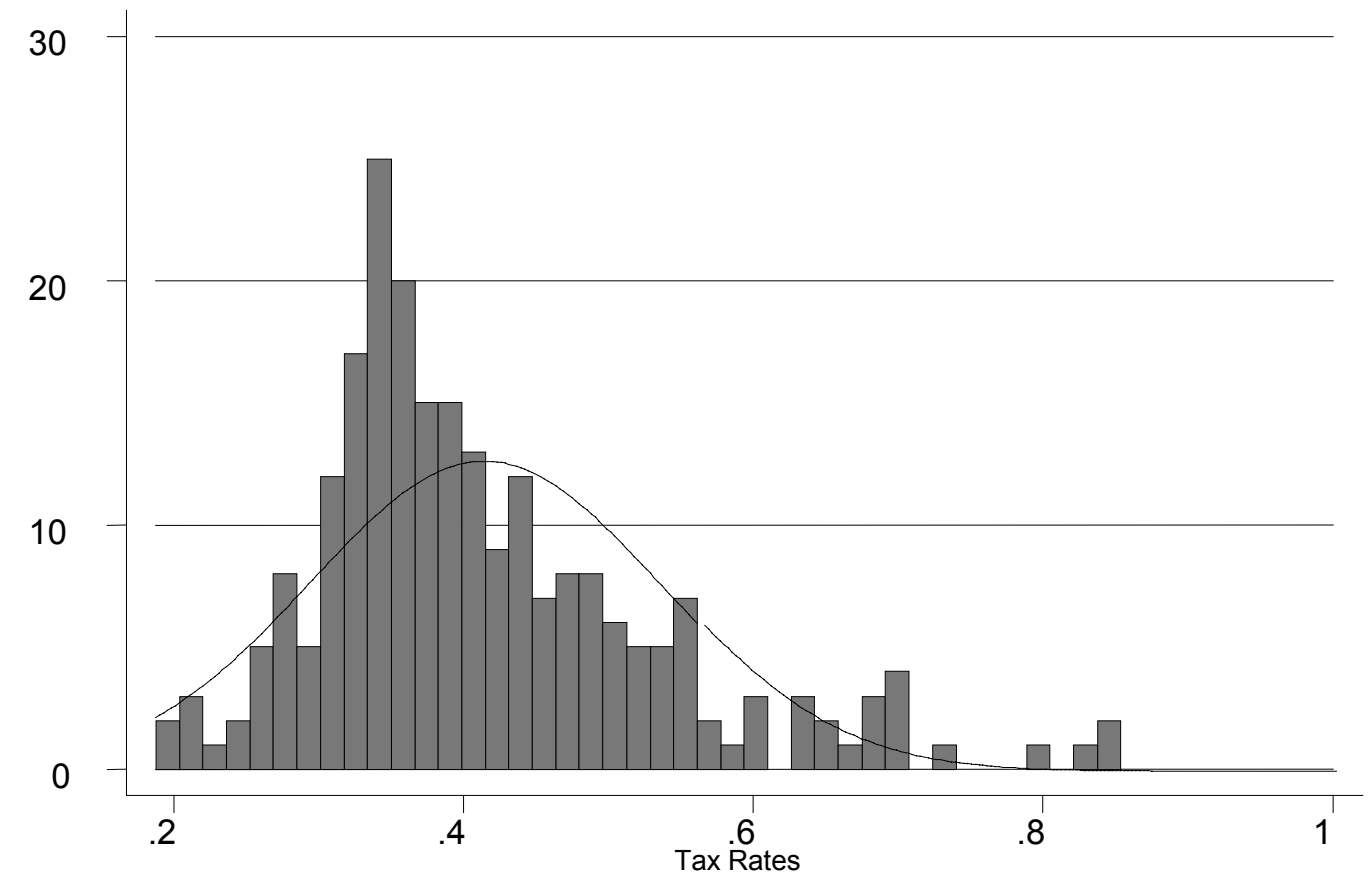

Figure 5: Average Tax Rates, 1993-94

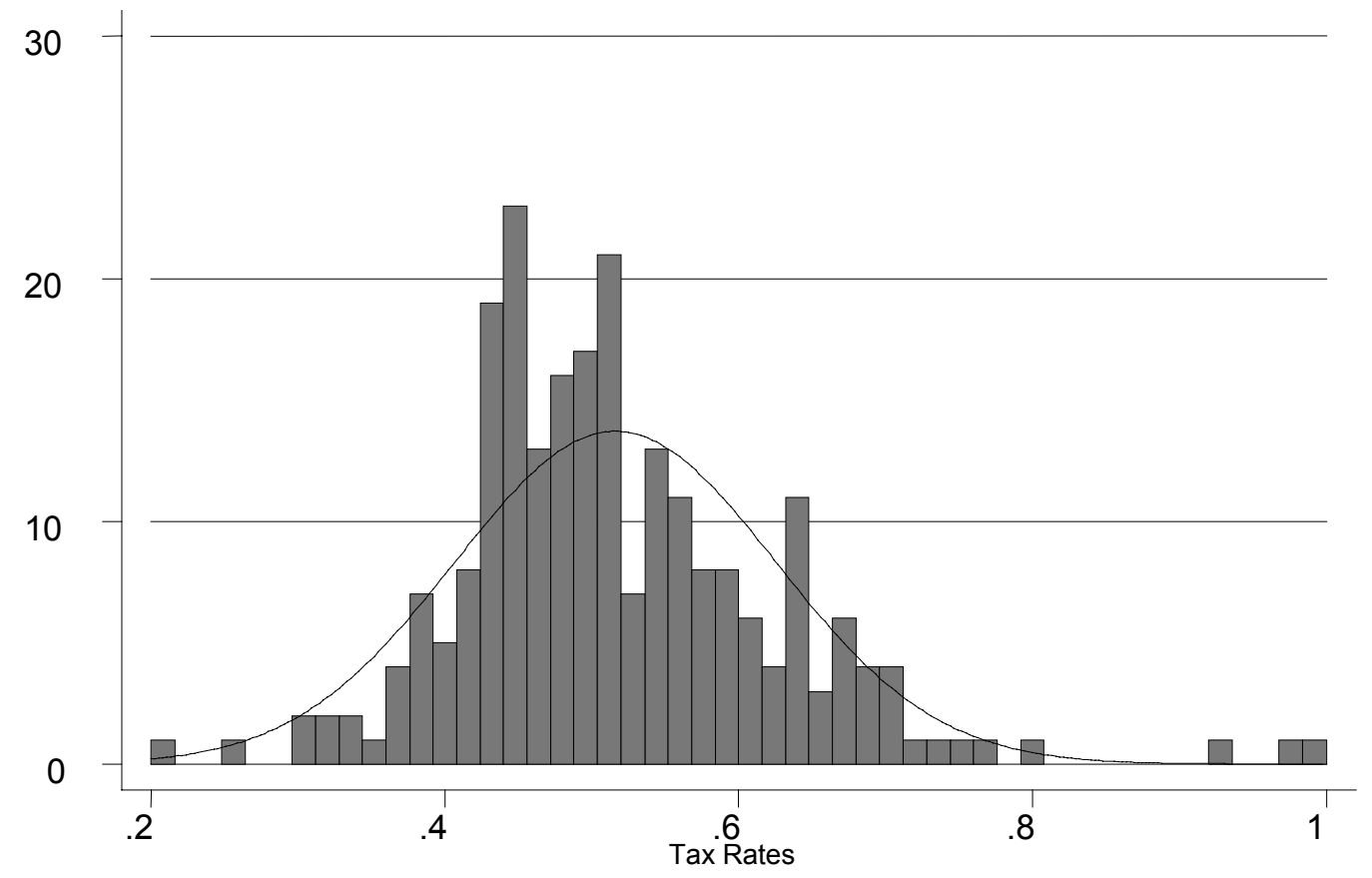


Figure 6: Average Tax Rates, 1995-96

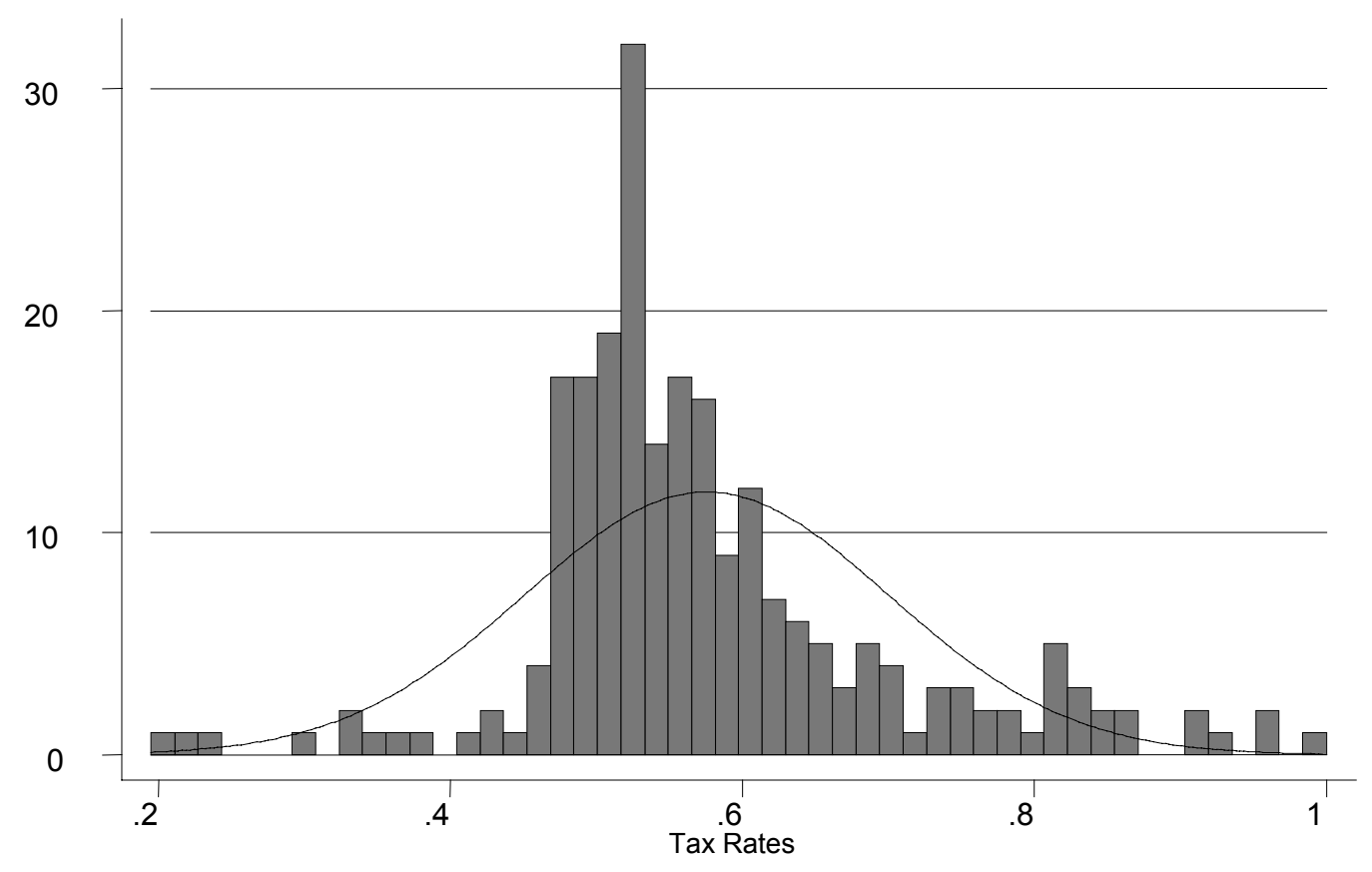


Table 1: Composition of Mandatory Non-Wage Labor Costs, 1980-1996

\begin{tabular}{|c|c|c|c|c|c|c|c|c|}
\hline $\begin{array}{l}\text { Non-Wage } \\
\text { Labor Costs }\end{array}$ & 1980 & 1982 & 1985 & 1989 & 1992 & 1994 & 1995 & 1996 \\
\hline Pensions & $4.5 \%$ & $4.5 \%$ & $6.5 \%$ & $6.5 \%$ & $8.0 \%$ & $11.5 \%$ & $12.5 \%$ & $\begin{array}{c}13.5 \%- \\
14.5 \%\end{array}$ \\
\hline Health & $7.0 \%$ & $7.0 \%$ & $7.0 \%$ & $7.0 \%$ & $7.0 \%$ & $7.0 \%$ & $8.0 \%$ & $12.0 \%$ \\
\hline Work Injury & $\begin{array}{c}0.35 \%- \\
8.7 \%\end{array}$ & $\begin{array}{c}0.35 \%- \\
8.7 \%\end{array}$ & $\begin{array}{c}0.35 \%- \\
8.7 \%\end{array}$ & $\begin{array}{c}0.35 \%- \\
8.7 \%\end{array}$ & $\begin{array}{c}0.35 \%- \\
8.7 \%\end{array}$ & $\begin{array}{c}0.35 \%- \\
8.7 \%\end{array}$ & $\begin{array}{c}0.35 \%- \\
8.7 \%\end{array}$ & $\begin{array}{c}0.35 \%- \\
8.7 \%\end{array}$ \\
\hline $\begin{array}{l}\text { In-kind } \\
\text { Transfers }\end{array}$ & $2.0 \%$ & $2.0 \%$ & $2.0 \%$ & $3.0 \%$ & $3.0 \%$ & $3.0 \%$ & $3.0 \%$ & $3.0 \%$ \\
\hline $\begin{array}{l}\text { Family } \\
\text { Allowances }\end{array}$ & $4.0 \%$ & $4.0 \%$ & $4.0 \%$ & $4.0 \%$ & $4.0 \%$ & $4.0 \%$ & $4.0 \%$ & $4.0 \%$ \\
\hline Training & $1.0 \%$ & $2.0 \%$ & $2.0 \%$ & $2.0 \%$ & $2.0 \%$ & $2.0 \%$ & $2.0 \%$ & $2.0 \%$ \\
\hline $\begin{array}{l}\text { Paid } \\
\text { Vacations }\end{array}$ & $4.15 \%$ & $4.15 \%$ & $4.15 \%$ & $4.15 \%$ & $4.15 \%$ & $4.15 \%$ & $4.15 \%$ & $4.15 \%$ \\
\hline $\begin{array}{l}\text { Mandatory } \\
\text { Bonuses }\end{array}$ & $4.15 \%$ & $4.15 \%$ & $4.15 \%$ & $4.15 \%$ & $4.15 \%$ & $4.15 \%$ & $4.15 \%$ & $4.15 \%$ \\
\hline $\begin{array}{l}\text { Severance } \\
\text { Pay }\end{array}$ & $8.33 \%$ & $8.33 \%$ & $8.33 \%$ & $8.33 \%$ & $8.33 \%$ & $8.33 \%$ & $8.33 \%$ & $8.33 \%$ \\
\hline Total & $\begin{array}{c}35.48 \%- \\
43.78 \%\end{array}$ & $\begin{array}{c}36.48 \%- \\
44.83 \%\end{array}$ & $\begin{array}{c}38.48 \%- \\
46.83 \%\end{array}$ & $\begin{array}{c}39.43 \%- \\
47.83 \%\end{array}$ & $\begin{array}{c}40.98 \%- \\
48.33 \%\end{array}$ & $\begin{array}{c}44.48 \%- \\
52.83 \%\end{array}$ & $\begin{array}{c}46.48 \%- \\
54.83 \%\end{array}$ & $\begin{array}{c}51.48 \%- \\
60.83 \%\end{array}$ \\
\hline
\end{tabular}

Notes: Work injury compensation taxes only apply to workers in manufacturing and commerce and depend on the degree of risk faced by the firm. In 1996, payroll tax contributions for pensions increased from $12.5 \%$ to $13.5 \%$ for employers of workers earning less than four minimum wages and to $14.5 \%$ for employers of workers earning more than four minimum wages. The paid vacations and bonuses contributions reported in the table are the minimum paid vacations and bonuses mandated by law, but firms' contributions for paid vacations and bonuses may vary because some firms offer their employees paid vacations and bonuses above these minimum levels. Prior to the labor market reform of 1990, severance pay were paid upon separation. After the reform, they were turned into recurrent costs, like payroll taxes, deposited in an individual savings accounts on a monthly basis. 
Table 2: Time Series Data on the Labor Market

\begin{tabular}{|c|c|c|c|c|c|c|}
\hline Year & $\mathrm{N}$ & Average Tax Rate & $\begin{array}{c}\text { Average Log Real } \\
\text { Wage }\end{array}$ & $\begin{array}{l}\text { Average Log } \\
\text { Total } \\
\text { Employment }\end{array}$ & $\begin{array}{c}\text { GDP } \\
\text { Growth }(\%)\end{array}$ & $\begin{array}{c}\text { Per Capita } \\
\text { GDP Growth } \\
(\%)\end{array}$ \\
\hline 1982 & 235 & $\begin{array}{c}0.4711 \\
(0.2196)\end{array}$ & $\begin{array}{c}4.9201 \\
(0.4049)\end{array}$ & $\begin{array}{c}3.7782 \\
(1.0868)\end{array}$ & 0.9 & -1.3 \\
\hline 1983 & 235 & $\begin{array}{c}0.4816 \\
(0.2291)\end{array}$ & $\begin{array}{c}5.4654 \\
(0.4149)\end{array}$ & $\begin{array}{c}3.7787 \\
(1.0762)\end{array}$ & 1.6 & -0.6 \\
\hline 1984 & 235 & $\begin{array}{c}0.4877 \\
(0.2204)\end{array}$ & $\begin{array}{c}5.4843 \\
(0.4016)\end{array}$ & $\begin{array}{l}3.8173 \\
(1.053)\end{array}$ & 3.4 & 1.3 \\
\hline 1985 & 235 & $\begin{array}{c}0.4845 \\
(0.2113)\end{array}$ & $\begin{array}{c}5.6176 \\
(0.3817)\end{array}$ & $\begin{array}{c}3.8084 \\
(1.0204)\end{array}$ & 3.1 & 1.1 \\
\hline 1986 & 235 & $\begin{array}{c}0.5051 \\
(0.2229)\end{array}$ & $\begin{array}{c}5.7898 \\
(0.3924)\end{array}$ & $\begin{array}{l}3.8217 \\
(0.988)\end{array}$ & 5.8 & 3.8 \\
\hline 1987 & 235 & $\begin{array}{c}0.5363 \\
(0.2104)\end{array}$ & $\begin{array}{l}5.9577 \\
(0.378)\end{array}$ & $\begin{array}{c}3.8486 \\
(1.01684)\end{array}$ & 5.4 & 3.4 \\
\hline 1988 & 235 & $\begin{array}{c}0.546 \\
(0.212)\end{array}$ & $\begin{array}{c}6.0238 \\
(0.4123)\end{array}$ & $\begin{array}{c}3.8468 \\
(1.0269)\end{array}$ & 4.1 & 2.1 \\
\hline 1989 & 235 & $\begin{array}{c}0.5728 \\
(0.2429)\end{array}$ & $\begin{array}{l}6.4237 \\
(0.381)\end{array}$ & $\begin{array}{c}3.8597 \\
(1.0664)\end{array}$ & 3.4 & 1.5 \\
\hline 1990 & 235 & $\begin{array}{c}0.5787 \\
(0.2418)\end{array}$ & $\begin{array}{c}6.5145 \\
(0.3837)\end{array}$ & $\begin{array}{c}3.8517 \\
(1.0924)\end{array}$ & 4.3 & 2.4 \\
\hline 1991 & 235 & $\begin{array}{c}0.5839 \\
(0.2611)\end{array}$ & $\begin{array}{c}7.0361 \\
(0.3941)\end{array}$ & $\begin{array}{c}3.8807 \\
(1.1227)\end{array}$ & 2.0 & 0.2 \\
\hline 1992 & 235 & $\begin{array}{l}0.4967 \\
(0.212)\end{array}$ & $\begin{array}{c}7.5365 \\
(0.4676)\end{array}$ & $\begin{array}{c}3.4766 \\
(1.3396)\end{array}$ & 4.0 & 2.2 \\
\hline 1993 & 235 & $\begin{array}{c}0.5494 \\
(0.1979)\end{array}$ & $\begin{array}{c}8.1597 \\
(0.3983)\end{array}$ & $\begin{array}{c}4.0117 \\
(1.1172)\end{array}$ & 5.4 & 3.6 \\
\hline 1994 & 235 & $\begin{array}{c}0.539 \\
(0.1697)\end{array}$ & $\begin{array}{c}7.8514 \\
(0.4332)\end{array}$ & $\begin{array}{c}3.4537 \\
(1.2439)\end{array}$ & 5.8 & 4.0 \\
\hline 1995 & 235 & $\begin{array}{c}0.5923 \\
(0.1946)\end{array}$ & $\begin{array}{l}8.3265 \\
(0.463)\end{array}$ & $\begin{array}{c}3.4469 \\
(1.2491)\end{array}$ & 5.8 & 3.9 \\
\hline 1996 & 235 & $\begin{array}{c}0.5979 \\
(0.1847)\end{array}$ & $\begin{array}{c}8.5849 \\
(0.4645)\end{array}$ & $\begin{array}{c}3.4089 \\
(1.2368)\end{array}$ & 2.0 & 0.2 \\
\hline
\end{tabular}

Notes: Tax rates are the employer contributions as a fraction of wages. Real wages are total wages over number of workers deflated using PPI. Standard deviations are in parenthesis. Data on GDP growth and per capita GDP growth were provided by DANE. 
Table 3: Estimates of the Effects of Payroll Taxes

on Wages and Employment, All Workers

\begin{tabular}{|c|c|c|c|c|c|c|c|}
\hline \multirow{2}{*}{$\begin{array}{l}\text { Sector- } \\
\text { specific } \\
\text { Trends }\end{array}$} & \multirow{2}{*}{$\begin{array}{l}\text { Firm- } \\
\text { specific } \\
\text { Trends }\end{array}$} & \multicolumn{2}{|c|}{ 1990's, Expansion Years } & \multicolumn{2}{|c|}{ 1980’s, Expansion Years } & \multicolumn{2}{|c|}{ 1980’s, Recession Years } \\
\hline & & Wages & Employment & Wages & Employment & Wages & Employment \\
\hline No & No & $\begin{array}{l}-0.1422 \\
(0.0112)\end{array}$ & $\begin{array}{l}-0.2725 \\
(0.0837)\end{array}$ & $\begin{array}{c}-0.1685 \\
(0.0602)\end{array}$ & $\begin{array}{l}-0.1925 \\
(0.0389)\end{array}$ & $\begin{array}{l}-0.1717 \\
(0.0691)\end{array}$ & $\begin{array}{l}-0.1638 \\
(0.0847)\end{array}$ \\
\hline Yes & No & $\begin{array}{l}-0.1869 \\
(0.0128)\end{array}$ & $\begin{array}{l}-0.3047 \\
(0.0933)\end{array}$ & $\begin{array}{c}-0.1746 \\
(0.0318)\end{array}$ & $\begin{array}{c}-0.2093 \\
(0.0343)\end{array}$ & $\begin{array}{c}-0.1752 \\
(0.0863)\end{array}$ & $\begin{array}{l}-0.2086 \\
(0.0704)\end{array}$ \\
\hline No & Yes & $\begin{array}{l}-0.2346 \\
(0.0883)\end{array}$ & $\begin{array}{l}-0.3841 \\
(0.1572)\end{array}$ & $\begin{array}{l}-0.2274 \\
(0.0435)\end{array}$ & $\begin{array}{l}-0.5031 \\
(0.0928)\end{array}$ & $\begin{array}{l}-0.1369 \\
(0.0625)\end{array}$ & $\begin{array}{c}-0.4983 \\
(0.0471)\end{array}$ \\
\hline
\end{tabular}

Notes: The table reports results from regressions of first-differences specifications without sector and year effects, with sector effects and with firm effects using data for 1993-94 and 1995-96 in the first two columns, using data for 1983-84 and 1989-90 for the expansion years in columns 3 and 4, and using data for 1984-85 and 1988-89 for the recession years in the last two columns. The specifications using pooled data for the 1980's include a production dummy. Standard errors are in parenthesis. 


\section{Table 4: Estimates of Effects of Payroll Taxes on Wages and Employment during the 1980's, Production and Non-production Workers}

\begin{tabular}{|c|c|c|c|c|c|c|c|c|c|}
\hline \multirow{3}{*}{$\begin{array}{l}\text { Sector- } \\
\text { specific } \\
\text { Trends }\end{array}$} & \multirow{3}{*}{$\begin{array}{l}\text { Firm- } \\
\text { specific } \\
\text { Trends }\end{array}$} & \multicolumn{4}{|c|}{ Expansion Years } & \multicolumn{4}{|c|}{ Recession Years } \\
\hline & & \multicolumn{2}{|c|}{ Production Workers } & \multicolumn{2}{|c|}{ Non-Production Workers } & \multicolumn{2}{|c|}{ Production Workers } & \multicolumn{2}{|c|}{ Non-Production Workers } \\
\hline & & Wages & Employment & Wages & Employment & Wages & Employment & Wages & Employment \\
\hline NO & NO & $\begin{array}{c}-0.0802 \\
(0.0485)\end{array}$ & $\begin{array}{c}-0.2782 \\
(0.0228)\end{array}$ & $\begin{array}{l}-0.2252 \\
(0.0532)\end{array}$ & $\begin{array}{l}-0.2119 \\
(0.0706)\end{array}$ & $\begin{array}{c}-0.0798 \\
(0.0394)\end{array}$ & $\begin{array}{c}-0.2094 \\
(0.0872)\end{array}$ & $\begin{array}{c}-0.1006 \\
(0.0644)\end{array}$ & $\begin{array}{c}-0.1944 \\
(0.0734)\end{array}$ \\
\hline YES & NO & $\begin{array}{c}-0.0683 \\
(0.0462)\end{array}$ & $\begin{array}{c}-0.4013 \\
(0.0608)\end{array}$ & $\begin{array}{c}-0.2683 \\
(0.0339)\end{array}$ & $\begin{array}{c}-0.2008 \\
(0.0742)\end{array}$ & $\begin{array}{c}-0.1094 \\
(0.0526)\end{array}$ & $\begin{array}{c}-0.3246 \\
(0.0764)\end{array}$ & $\begin{array}{c}-0.1897 \\
(0.0964)\end{array}$ & $\begin{array}{c}-0.1974 \\
(0.0471)\end{array}$ \\
\hline $\mathrm{NO}$ & YES & $\begin{array}{c}-0.1394 \\
(0.0647)\end{array}$ & $\begin{array}{l}-0.5492 \\
(0.0811)\end{array}$ & $\begin{array}{c}-0.2893 \\
(0.0697)\end{array}$ & $\begin{array}{c}-0.4897 \\
(0.0632)\end{array}$ & $\begin{array}{l}-0.1459 \\
(0.1046)\end{array}$ & $\begin{array}{c}0.5143 \\
(0.1247)\end{array}$ & $\begin{array}{l}-0.2753 \\
(0.0942)\end{array}$ & $\begin{array}{l}-0.4381 \\
(0.1127)\end{array}$ \\
\hline
\end{tabular}

Notes: The table reports results from regressions of first-differences specifications without sector and firm effects, with sector effects and with firm effects using data for 1983-84 and 1989-90 for the expansion years and using data for 1984-85 and 1988-89 for the recession years. Standard errors are in parenthesis. 